\title{
The control of keypecks during automaintenance by prekeypeck omission training*
}

\author{
GARY A. LUCAS \\ University of Missouri-Kansas City, Kansas City, Missouri 64110
}

\begin{abstract}
Measures of pigeons' prekeypecking (pecking in front of the response key) during automaintenance sessions with keypeck omission contingencies indicate that prekeypecks occur frequently and are often followed by grain delivery. When the omission procedure is extended to prevent food delivery following any trial on which prekeypecks occur within 2 in. of the response key, keypecking is not maintained. These results are taken to suggest that the automaintenance keypeck is part of a sequence of approach behaviors, including prekeypecks. The persistence of keypecking during automaintenance schedules appears to result from the adventitious reinforcement of prekeypecks close to the response key, and the effectiveness of the omission procedure seems to depend upon the extent of the approach behaviors which result in omission.
\end{abstract}

Brown and Jenkins (1968) demonstrated that hungry pigeons would peck at a stimulus key if food was regularly presented following the illumination of the key. Williams and Williams (1969) found that the tendency to peck at the stimulus signaling food would persist even when an omission contingency was used to prevent food delivery on trials during which keypecks occurred. They called this effect automaintenance.

Recent articles in this area have generally supported either a Pavlovian explanation of automaintenance (Gamzu \& Schwartz, 1973; Gamzu \& Williams, 1971, 1973; Wasserman, 1973b), or have suggested that phylogenetic determinants were responsible for pecking (Schwartz \& Williams, 1972b; Seligman \& Hager, 1972; Staddon \& Simmelhag, 1971). A few studies have explored response contingencies beyond the Williams and Williams (1969) study. Schwartz and Williams (1972a) reported that automaintenance keypecking was somewhat sensitive to omission training. They demonstrated that the number of keypecks directed at a stimulus was reduced when an alternative response key with an equivalent stimulus-reinforcer dependency, but no omission contingency, was concurrently available. Herrnstein and Loveland (1972) suggested that stimulus change, itself, may be reinforcing keypecks during omission training.

The present study was designed to explore another possible source of reinforcement. The author has previously observed in the laboratory that pigeons switched from contingent to noncontingent reinforcement schedules occasionally continue pecking

\footnotetext{
*This research was in partial fulfilment of the requirements for the degree of Master of Arts. The author wishes to express his thanks to his wife, Joanne, for her perceptive and empirical comments throughout the course of the study and to Diane Edwards for her support and guidance. Thanks are also due Donna Purdin for her help in preparation of the manuscript. Reprints may be obtained from the author, Department of Psychology, C. B. Annex, University of Missouri-Kansas City, Kansas City, Missouri 64110.
}

in front of a response key without consistently striking the key. Staddon and Simmelhag (1971, p. 13) also report this effect in their study, and Brown and Jenkins $(1968$, p. 6) have described a similar observation for one pigeon which stopped keypecking under a sustained autoshaping procedure. Since an omission training procedure provides no contingencies for pecking away from the response key, prekeypecking may frequently occur during omission training and still be followed by grain delivery. The following experiment, therefore, explored the effects of an omission training procedure for prekeypecking on the maintenance of keypecking during automaintenance sessions.

\section{METHOD}

\section{Subjects}

Three adult white Carneaux pigeons were maintained at $80 \%$ of their free-feeding weights. All three Ss had learned to keypeck via the autoshaping procedure and had demonstrated a tendency to continue pecking under automaintenance during 3 months' previous exposure to keypeck omission contingencies.

\section{Apparatus}

A standard Lehigh Valley Electronics Model 1519 pigeon chamber and a Model 1348 two-key test panel were used. Only the right response key was ever illuminated. The pigeon's experimental space was $12 \times 13 \times 13$ in. $(300 \times 330 \times 330 \mathrm{~mm})$. The response keys were centered 5 in. $(130 \mathrm{~mm})$ apart and 9 in. $(230 \mathrm{~mm})$ above the floor. The grain hopper was centered between the keys with an opening $4 \mathrm{in}$. $(100 \mathrm{~mm})$ above the floor. The houselight was centered $11 \mathrm{in} .(280 \mathrm{~mm})$ above the floor and was directed toward the ceiling. A minimum force of $0.12 \mathrm{~N}$, applied perpendicular to each key, was necessary to operate the microswitch. All programming equipment was housed in a separate room. White noise was continuously presented to mask the sound of the relay and recording equipment.

A Lehigh Valley Electronics Model 221-10 photosensor was used to measure the frequency of behavior in front of the response key. The emitter and receiver elements of the photosensor were mounted on each side of the right response key, 1.5 in. $(38 \mathrm{~mm})$ from the $\mathrm{rim}$ of the key, $0.5 \mathrm{in} .(13 \mathrm{~mm})$ 

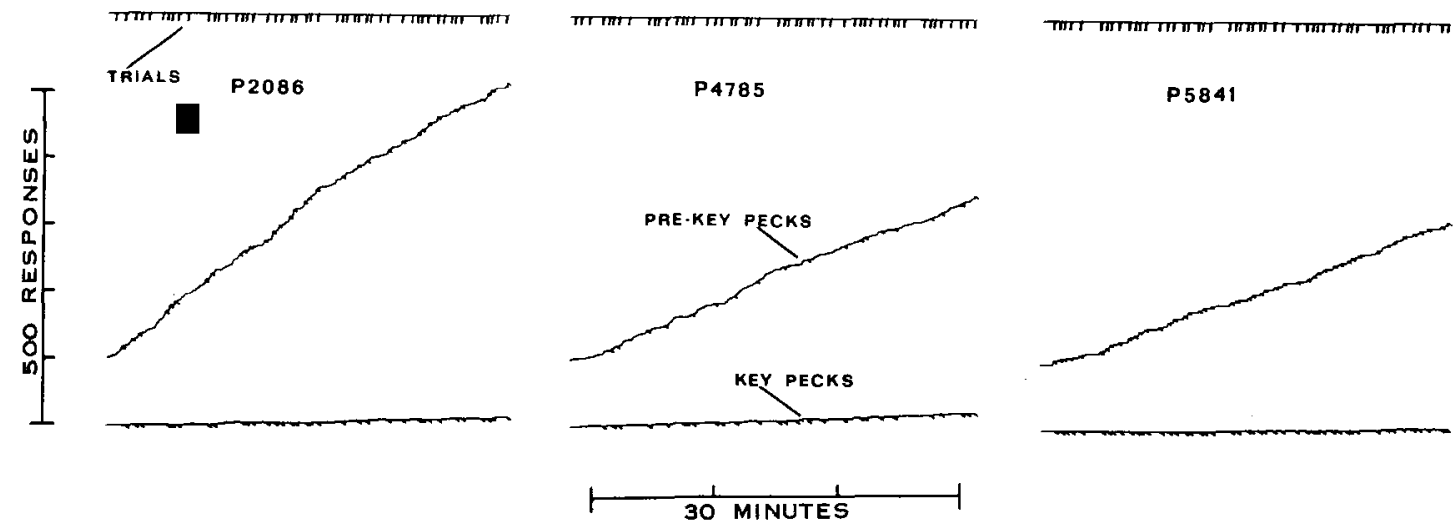

Fig. 1. Cumulative records for keypecks and prekeypecks. Records are presented from the final session under the keypeck omission procedure. The downward strokes on the keypeck record mark the presentation of grain following all trials during which no keypecks occurred. The downward strokes on the prekeypeck record mark only those presentations of grain which follow trials during which prekeypecks occurred. They ther efore represent occasions on which prekeypecking was reinforced while keypecking was not. The event marker at the top of each record indicates the presentation of the white keylight during each trial.

below the center of the key, and $1 \mathrm{in} .(25 \mathrm{~mm})$ in front of the key. This placement provided an opening of 4.0 in. (100 mm) between the emitter and receiver elements, through which the pigeon could approach the key. The photosensor elements were equipped with infrared lenses so that they would not compete with the lighted key. Any movement of the pigeon which interrupted the path between the emitter and receiver elements operated the photosensor and could be recorded. Visual observations on pigeons under the automaintenance contingency indicated that less than $3 \%$ of the photosensor counts were produced by behaviors other than nodding or pecking movements.

In a later portion of this study, the photosensor elements were extended to $2 \mathrm{in}$. $(51 \mathrm{~mm})$ in front of the response key, as part of a change in contingency.

\section{Procedure}

The following general procedures were common to all the discrete-trial procedures used in this study. Each trial consisted of a 6-sec illumination of the right response key, with a white light followed, when appropriate, by a 4-sec grain-delivery or grain-omission period. During this period, the houselight was turned out and the key color was changed to green during grain presentation or to red during grain omission. At the end of the 4-sec period, the keylight was turned out and the houselight was turned on. Trials were separated by an intertrial interval averaging $30 \mathrm{sec}$ and ranging from 10 to $90 \mathrm{sec}$. Each session lasted $33 \mathrm{~min}$ (48-52 trials). Each $\mathrm{S}$ was exposed to all the following procedures.

Discrete-Trial CRF. In order to assure that Ss began responding under the omission proced ure with a high probability of keypecking, they were first exposed to a continuous-reinforcement schedule. Under this procedure, the right response key was illuminated with a white light for 6-sec periods. If a keypeck occurred during the light, the key color was immediately changed to green, the houselight was turned off, and the grain hopper was presented for 4-sec. If no keypeck occurred, the light was terminated after $6 \mathrm{sec}$ and the intertrial interval was begun. Each $S$ remained under this schedule for a minimum of five sessions or until it began to keypeck on a minimum of $80 \%$ of the available trials per session for three consecutive sessions.

Keypeck-omission Training. In the subsequent sessions, each $\mathrm{S}$ was exposed to an omission training procedure. On each trial, the keylight was illuminated with white light for 6 sec. If no keypeck occurred during the white light, the keylight changed to green and grain was presented. A response to the key during the white light immediately produced a 4 -sec red light and no grain on that trial. Prekeypecking behavior was recorded, but no contingency was placed on it during this phase. S P2086 remained under this contingency for 19 sessions. Ss P4785 and P5841 remained under this contingency for 21 sessions.

One-inch Prekeypeck Omission. Under this procedure, the negative-response contingency was extended to include prekeypecking behavior within $1 \mathrm{in}$. $(25 \mathrm{~mm})$ of the key. That is, any peck or approach within 1 in. of the response key during the white light immediately turned on the red light and prevented the delivery of grain on that trial. If no keypeck or prekeypeck occurred during the white light, the keylight was changed to green and grain was presented. Each $\mathrm{S}$ remained under this procedure for 21 sessions.

Two-inch Prekeypeck Omission. In the next sessions, the prekeypeck omission procedure was extended to 2 in. $(51 \mathrm{~mm})$ in front of the response key. That is, any peck or approach within $2 \mathrm{in}$. of the response key during the white light immediately turned the keylight red and prevented the delivery of grain on that trial. In order to extend the prekeypeck omission procedure, it was necessary to move the photosensor elements 2 in. in front of the response key. All other conditions were identical to the previous procedure. Each $S$ remained under this procedure for 10 sessions.

Unsignaled Omission Training. Under the preceding omission procedure, the white light is terminated whenever an $S$ approaches the response key. While this proced ure punishes prekeypecking behavior, it also reduces the opportunity for an $S$ to respond to the white keylight. That is, if an S pecks close to the key but does not strike the key on its first peck, the keylight will change to red, thus preventing the opportunity to peck the key during the white light on that trial. In order to isolate the effects of this limited opportunity to keypeck from the effects of the prekeypeck omission contingency, each $S$ was exposed to an unsignaled omission procedure. Under this procedure, any peck or approach within 2 in. of the response key during the white light prevented the delivery of grain on that trial but did not terminate the trial. Instead, the white light remained on for $6 \mathrm{sec}$; independent of behavior. Thus, each $S$ had the opportunity to peck the key during the white light for the complete 6-sec duration on each trial. All Ss were exposed to this unsignaled procedure for 21 sessions.

\section{RESULTS}

When the omission procedure prevented 
Table 1

Percentage of Total Trials Per Session During Which Prekeypeck (PKP) and Keypeck (KP) Occurred

\begin{tabular}{|c|c|c|c|c|c|c|}
\hline \multirow[b]{3}{*}{ Conditions } & \multicolumn{6}{|c|}{ Pigeons } \\
\hline & \multicolumn{2}{|c|}{ P 2086} & \multicolumn{2}{|c|}{ P 4785} & \multicolumn{2}{|c|}{ P 5841} \\
\hline & PKP & KP & PKP & KP & PKP & KP \\
\hline Discrete Trial CRF* & 100 & 92.6 & 96.0 & 89.0 & 99.3 & 96.3 \\
\hline Keypeck Omission & 99.6 & 27.6 & 77.2 & 40.6 & 97.6 & 5.60 \\
\hline 1-in. Prekeypeck Omission & 33.6 & 0.00 & 40.0 & 9.60 & 48.0 & 0.80 \\
\hline 2-in. Prekeypeck Omission & 37.2 & 0.00 & 3.60 & 0.00 & 40.4 & 0.00 \\
\hline Unsignaled Omission & 39.6 & 0.00 & 4.80 & 0.00 & 59.2 & 0.00 \\
\hline
\end{tabular}

Note-The data are means across the last five sessions of each condition except as noted.

*Means across last three sessions.

reinforcement only on those trials during which keypecks occurred, keypecks were nevertheless maintained (automaintenance). Records of prekeypecking during this schedule show that, on trials during which no actual keypecks occurred, prekeypecks often occurred and were subsequently followed by the delivery of grain. Figure 1 presents the cumulative records for both keypecks and prekeypecks (within 1 in. of the response key) from the final session under the keypeck omission procedure.

These records demonstrate that a relatively stable pattern of prekeypecking was being maintained during keypeck omission training. Thus, despite the omission procedure, pecking movements in the direction of the key continued to occur and were often followed by grain delivery. The percentage of trials in which prekeypecks occurred under this procedure is given in Table 1.

When the omission procedure was extended to include prekeypecking, keypecking was not maintained. The keypeck data in Table 1 show that keypecking was completely eliminated in one $S$ and substantially reduced in the other two when prekeypecks within $1 \mathrm{in}$. of the key resulted in grain omission. No keypecks were maintained under the 2-in. prekeypeck omission procedure.

When the omission procedure was unsignaled so that Ss had an increased opportunity to keypeck, each $S$ showed a slight initial recovery of keypecks, but keypecking was not maintained. Inspection of the individual records indicates that the decrease in keypecking under the prekeypeck omission procedures was not systematically related to a decrease in the percentage of trials on which grain was delivered. Instead, the decrease in keypecking appears to be a direct result of omission training for pecking movements close to the key.

Prekeypecking, however, was not eliminated by prekeypeck omission training. Instead, the data in Table 1 demonstrate that, although the percentage of prekeypeck trials was partially reduced by the omission procedure, prekeypecking continued to occur in all Ss at a substantial level. That is, prekeypecking under this procedure acted like keypecking under keypeck omission training and was, instead, maintained.

\section{DISCUSSION}

The aim of the present study was to examine the role of prekeypecking during automaintenance. The results can be summarized as demonstrating: (1) that pigeons under keypeck omission training frequently pecked in front of the response key, (2) that prekeypecking was often followed by grain delivery, and (3) that an omission contingency which prevented food delivery following trials during which prekeypecks occurred within 2 in. of the key, eliminated keypecking but not prekeypecking. These findings are taken to indicate that a low level of keypecking may be maintained during automaintenance schedules by the adventitious reinforcement of prekeypecks close to the response key, despite keypeck omission training.

Wessels (1974) has shown that keypecking and prekeypecking behaviors (including approach behaviors) are closely related during autoshaping. That is, keypecking and prekeypecking behaviors are not independent but, rather, contingencies applied to one behavior also affect the other. The nonindependence of keypecking and offkeypecking is also supported by the frequent appearance of offkeypecking during punishment procedures (Bachrach, 1966; Dunham, Mariner, \& Adams, 1969), response-independent procedures (Staddon \& Simmelhag, 1971), and other autoshaping procedures (Brown \& Jenkins, 1968; Wasserman, 1973a). The present study supports these findings and suggests that the failure of keypeck omission training to eliminate keypecking during automaintenance schedules results because prekeypecks similar in location and topography to keypecks are adventitiously reinforced during automaintenance schedules.

One difference between the present study and Wessels's study which may provide some insight into prepecking behaviors involves the effects of omission training for prepecking. Wessels reported that, when grain omission resulted from any approach into the left 
front quarter of the chamber (the area closest to the response key), all pecking and approach within that space ceased. Judging from the dimensions of the chamber, this procedure resulted in omission for any approach within a distance varying from about 3.5 to $5.0 \mathrm{in}$. ( 89 to $127 \mathrm{~mm}$ ) from the key, depending partially on the direction of approach. In the present study, prekeypeck omission training for approaches within 2 in. of the key reduced, but did not eliminate, prekeypecks within the 2-in. space. Apparently, the approach and keypeck sequence contained a sufficient number of movements beyond the 2-in. space so that partial approach was still adventitiously strengthened, but not a sufficient number of behaviors beyond the 5 -in. space to maintain approach despite omission training. These differences suggest that the amount of control which an omission contingency exerts over one given behavior, from a sequence of nonindependent behaviors, depends partially on the extent to which the contingency is applied to earlier members of the sequence.

The ineffectiveness of the keypeck omission procedures during automaintenance (Williams \& Williams, 1969) appears to result from the adventitious strengthening of prekeypecking, as described in the present study, and the nonindependence of pecking and prepecking behaviors reported by Wessels (1974). These results, together with previous findings regarding the conditions necessary for autoshaping, seem to provide a plausible explanation for automaintenance.

\section{REFERENCES}

Bachrach, A. J. A simple method of obtaining a scatter distribution of off-key pigeon pecking. Journal of the
Experimental Analysis of Behavior, 1966, 9, 152

Brown, P. L., \& Jenkins, H. M. A uto-shaping of the pigeon's keypeck. Journal of the Experimental Analysis of Behavior, $1968,11,18$.

Dunham, P. J., Mariner, A, \& Adams, H. Enhancement of off-key pecking by on-key punishment. Journal of the Experimental A nalysis of Behavior, 1969, $12,789-797$.

Gamzu, E., \& Schwartz, B. The maintenance of key pecking by stimulus-contingent and response-independent food presentations. Journal of the Experimental Analysis of Behavior, 1973, 19, 65-72.

Gamzu, E., \& Williams, D. R. Classical conditioning of a complex skeletal response. Science, 1971, 171, 923-925.

Gamzu, E.. \& Williams, D. R. A ssociative factors und erlying the pigeon's key pecking in auto-shaping procedures. Journal of the Experimental Analysis of Behavior, 1973, 19, 225-232.

Herrnstein, R. J., \& Loveland, D. H. Food avoidance in hungry pigeons, and other perplexities. Journal of the Experimental Analysis of Behavior, 1972, 18, 369-383.

Schwartz, B. \& Williams, D. R. The role of the response-reinforcer contingency in negative auto maintenance. Journal of the Experimental Analysis of Behavior, 1972a, 17, 351-357.

Schwartz, B., \& Williams, D. R. Two different kinds of keypeck in the pigeon: Some properties of responses maintained by negative and positive response-reinforcer contingencies. Journal of the Experimental A nalysis of Behavior, 1972b, 18 , 201-216.

Seligman, M. E. P., \& Hager, J. L. Biological boundaries : of learning. New York: Appleton-Century-Crofts, 1972.

Stadd on, J. E. R., \& Simmelhag, V. L. The "superstition" experiment: A reexamination of its implications for the principles of adaptive behavior. Psychological Review, 1971, $78,3-43$.

Wasserman, E. A. The effect of redundant contextual stimuli on autoshaping the pigeon's key peck. Animal Learning and Behavior, 1973a, 1, 198-206.

Wasserman, E. A. Pavlovian conditioning with heat reinforcement produces stimulus-directed pecking in chicks. Science, 1973b, 1, 198-206.

Wessels, M, G. The effect of reinforcem ent upon the pre-pecking behaviors of pigeons in the autoshaping experiment. Journal of the Experimental Analysis of Behavior, 1974, 21, 125-144.

Williams, D. R. \& Williams, H. Auto-maintenance in the pigeon: Sustained pecking despite contingent non-reinforcement. Journal of the Experimental Analysis of Behavior, 1969, 12, 511-520.

(R eceived for publication January 10, 1974; revision accepted August $7,1974$. ) 